\title{
Women 'leaders' in local government in the UK
}

Catherine Bochel and Hugh Bochel

Department of Policy Studies

Faculty of Health, Life and Social

Sciences

University of Lincoln

Brayford Pool

Lincoln

LN6 7TS

Tel: + 44 (0) 1522886098

E-mail: hbochel@lincoln.ac.uk 


\begin{abstract}
This article draws upon research undertaken in the United Kingdom in 2006 which examined aspects of the 'leadership' roles and functions of female and male councillors. The article highlights the continued under representation of women in terms of the proportion of councillors who are women, and the 'gender gap' that exists in terms of council leadership and the portfolios that men and women hold on council cabinets or executives. It moves on to a consideration of qualitative evidence that suggests that there are similarities and differences in the way that female and male councillors in leadership positions perceive of their roles and styles.
\end{abstract}


A consideration of the position of women in elected local government in England, Scotland and Wales is pertinent for three main reasons: firstly, there has been a slow but steady increase in the proportion of councillors who are women over the last thirty years; secondly, there have been a number of changes to local government in the United Kingdom which have led to questions over the role of councillors, including around 'leadership'; and thirdly debates over descriptive and substantive representation have encouraged questions as to what difference women councillors might make.

From the late 1990s the government has placed considerable emphasis upon local leadership, arguing, for example, that 'Whatever the causes, the Government believes that the failure to maximise the potential of locally elected representatives to act in a leadership role as advocates and champions of local communities is a major obstacle to our ambitions for civil renewal and improved public services'. ${ }^{1}$ Consequently local government in the United Kingdom, particularly in England and Wales, has been 'encouraged', as part of central government's modernisation agenda, to adopt new forms of decision-making structures, based upon the view that these would be more efficient, and would enhance accountability and local leadership through a clearer linkage of individuals to policy making and to outcomes (in Scotland greater attention has arguably been paid to the electoral system, with the introduction of the single transferable vote system for local government elections from May 2007). These new structures have focused upon the replacement of the traditional committee system with leaders and cabinets, leaving the majority of councillors as 'backbenchers, although in a small number of instances local authorities have shifted to directly elected mayors.

The government has continued to emphasise that it wishes to see more visible local leadership, and in late 2006 published a White Paper for England, Strong and Prosperous Communities, Chapter 3 of which includes discussion of 'More diverse and representative councillors', 'Councillors as democratic champions' and 'Stronger leadership'. Under the latter heading, the White Paper states that 'The Government believes that it is important that councils move towards having more stable and more visible political leadership. Our research shows that leadership is the single most significant driver of change and improvement in local authorities, ${ }^{2}$ and contains a promise to legislate so that in future there will be three models of executive arrangement: a directly elected mayor with a four year term; a directly elected executive with a four year term; or an indirectly elected leader with a four year term. In each of these models the government states that 'all executive powers will be vested in the mayor or leader', making that role even more important. 
As part of the programme of modernisation since 1997, including local government, the Labour government has recognised that 'Elected representatives are a long way from being broadly representative of the communities that they serve' in terms of gender, age and 'race', and that 'Being representative means being able to attract more women and more people from a range of diverse backgrounds', implying at the least an acceptance of some of the arguments for greater equality of representation and descriptive representation. ${ }^{3}$ However, the government has also stated that 'There is no evidence to suggest... that the election of women or ethnic minority councillors necessarily means equalities are improved or introduced into employment and/or services within local government... It should also be noted that it is not necessarily the case that a councillor who is from a particular group will identify with and understand the needs and circumstances of that group', again touching upon debates around descriptive and substantive representation. ${ }^{4}$ In the 2006 White Paper for England, Strong and Prosperous Communities, the government developed an argument more closely related to utility, and in particular legitimacy, suggesting that 'If democratic representatives are to command the confidence of their communities then they need to reflect the diversity of their local communities. Groups that are under-represented are more likely to believe that their perspectives are overlooked and disengage from the democratic process'.5

It has sometimes been argued that local government has been more accessible to women than national politics, for example, being inevitably more local, making it easier to integrate the potential demands of work, family and political life; having more seats and less competition for them; and being more open for women generally, as reflected in the promotion of equal opportunities for women staff and having women's issues more firmly on the agenda.

It is worth noting that involvement in local government is important (in the UK at least) also because it is a significant training ground and pathway into national politics. Wilson and Game point out that following the 1997 general election 56\% of MPs (62\% of the 1997 intake) had experience as councillors, ${ }^{6}$ while in the first Scottish Parliament $40 \%$ of MSPs had local government experience ${ }^{7}$ and in the first National Assembly for Wales $38 \%$ of AMs had been councillors. ${ }^{8}$

These debates clearly reflect those around descriptive representation. Where women are concerned Phillips has argued for the 'politics of presence', including to address past and continued injustices which require that trust be given only to descriptive representatives, to allow historically excluded groups to get their ideas, issues and perspectives on the political agenda, and to revitalise democracy by demonstrating a commitment to diverse representation which in turn will encourage greater participation and legitimacy for democratic institutions. ${ }^{9}$ 
From another perspective, analysing the 2001 British Election Survey, Campbell has suggested that there are gender differences in policy priorities between men and women in the United Kingdom, with women being more likely to prioritise education and healthcare issues, and men more likely to see the economy as the most important election issue, which she argues supports Phillips' call for gender quotas as 'there is evidence that men and women want slightly different things from the political system and these differences need to be represented in order for a meaningful debate to ensue'. ${ }^{10}$ Similarly Mansbridge has argued that democracy works better if there is 'proportional descriptive representation', with disadvantaged groups requiring full levels of representation for a variety of reasons including critical mass, dispersion of influence and a range of views within the group. ${ }^{11}$ For such writers it is generally women's life experience that links descriptive and substantive representation, with that life experience making it more likely that women representatives will take up women's issues.

There is clearly a potential weakness in the attempts to suggest that including individual members of a group, such as women, is sufficient to represent the group's perspective, and if a white middle class woman cannot speak for a black woman or a poor woman, how can they represent the collective experience of women as a group. Young recognises that there are differences between the represented and their representatives and argues that these have to be acknowledged and affirmed. However, she also suggests that what is necessary is accountability and authorisation, rather than simply descriptive representation. ${ }^{12}$ Given the complex and dynamic nature of representation the important thing is therefore to ensure that citizens can appropriately choose their representatives and hold them accountable, so that any assessment of representation will depend upon the behaviour of representatives.

However, Dovi criticises this view, giving as an example Young's claim that an Asian American could have the perspective of an African American, arguing that 'If Asian Americans can possess an African-American perspective and thereby satisfy the requirements of being descriptive representatives for African-Americans, so can whites' ${ }^{13}$ Dovi notes that few of those arguing for greater descriptive representation (greater presence) have said anything about the criteria by which such representatives should be chosen. She argues that there is a need for such criteria in part because there are many differences within groups, whilst also suggesting that these representatives, whilst paying special attention to overlooked interests, should retain the autonomy to 'reasonably interpret those interests in a variety of ways'. She therefore argues that the criterion for identifying these individuals should be that 'Preferable descriptive representatives have strong mutual relationships with dispossessed subgroups', with the mutuality being grounded in a mutual recognition and interactive 
relationship between representatives and represented, and dispossession referring to groups that are unjustifiably excluded from or by the political process and which thus lack the political and economic resources necessary for effective representation.

Closely allied to the idea of descriptive representation in relation to women and politics has been the concept of 'critical mass', with the notion that as the proportion of women in elected assemblies increases, this will in turn lead to better levels of substantive representation and that at some stage (varying from levels of around 15 to $40 \%$ ) political behaviour, policy agendas (including greater attention to women's issues) and institutions will be transformed. However, whilst this view has led to increased attention being paid to the levels of women representatives, it has also been criticised as, for example, individuals do not necessarily 'stand for or speak for the groups that they come from, higher proportions of women in assemblies do not necessarily lead to changed agendas, whilst it is also the case that smaller proportions of women can be effective in bringing new issues on to the agenda'. ${ }^{14}$

The ideas of descriptive and substantive representation, and of critical actors, Celis et al [AS DISCUSSED BY CELIS ET AL IN THIS ISSUE?] ${ }^{15}$ are also relevant to debates around political leadership. While there has been debate about the links between descriptive and substantive representation, and the importance of positional power in facilitating the substantive representation of women, ${ }^{16}$ the increasing emphasis on leadership at local and regional level in recent years means that any 'under-representation' of women (or of any other 'minority' groups) may be exacerbated by the greater centralisation of power on one individual (such as an elected mayor) or a small group of individuals (in the case of leader and cabinet/executive models), as well as by the apparently growing difference between 'frontbench' and 'backbench' or non-executive councillors, ${ }^{17}$ as, if most of the senior postholders are male, the representation of women would effectively be decreased in terms of decision making positions and power within local authorities.

\section{Methods}

There were effectively two stages to the empirical elements of this work. The first involved the collection and analysis of secondary data from local authorities in England, Scotland and Wales on the models of decision-making adopted, the numbers of male and female councillors, the proportions of female and male councillors in senior positions, and, where relevant, the portfolios for which they were responsible. This was gathered primarily through the examination of authorities' web pages, supplemented by examination of The Municipal Yearbook, and, where necessary, by telephone or email contact with councils. This provided a comprehensive picture of the position as at May 2006. 
The second phase of the research involved in-depth, largely qualitative interviews, either conducted face-to-face or by telephone, with 36 individuals in leadership positions from a variety of forms or authority (county and district councils, London boroughs, English unitary and Scottish and Welsh councils), from the three main political parties and independents, and from councils with one party majorities, coalitions and minority administrations. There are always potential risks in approaches that rely upon self-reporting, but in this instance, with all interviews being conducted on a confidential basis, with there being no potential benefit or risk to individuals in terms of either positive publicity or fit with party policy, there was no reason for respondents to speak with less than absolute candour, and indeed the willingness of many to give their views in a forthright and open manner, even when potentially clashing with party positions, suggests that they did so.

This analysis concentrates on England, Scotland and Wales (Northern Ireland is excluded), but in general reference is only made to each of these countries where there is a significant degree of difference across them.

\section{The descriptive representation of women in local government}

Local government councillors in the United Kingdom remain far from descriptively representative - well under one-third are female, only four per cent are non-white, and more than half are aged over 60 . They are also more likely to be educated to degree level than the rest of the population, and are more likely to come from managerial or professional-type occupations, although many are not in employment, including as a result of retirement and/or because they have become full-time councillors.

Almost regardless of the debates around descriptive and substantive representation of women, there remain important issues, including in relation to justice and participation, and the limited numbers of women (and for that matter other groups, such as black people and disabled people) who have traditionally been candidates for and elected to local government in the United Kingdom. As noted above, since 1997 this is something that the Labour government has paid some attention to as part of its 'modernisation' agenda, including through discussion of 'representativeness', although, as noted elsewhere ${ }^{18}$ and as the local government White Paper recognises, there are other associated issues such as trust in and legitimacy of the political system, and the danger of continued marginalisation of some groups. 
One thing that is clear from any examination of the figures is that there has been a slow but steady increase in the proportions of elected positions held by women in the United Kingdom, both within the Westminster Parliament and at the local level. In parliament there was a very slow increase from 4\% of MP being women in 1945 to $9 \%$ in 1992 and then a jump to $18 \%$ in 1997, largely as a result of the Labour Party's decision to adopt all-women shortlists as part of the selection process. The current figure is just under twenty per cent; in addition one of the early actions of David Cameron when he became leader of the Conservative Party, was to signal a desire to increase the number of women contesting winnable seats for his party, although whether this initiative will prove successful remains unclear. Within local government, since the reorganisations of 1973/4 there has also been a slow but clear trend of increasing numbers of women standing as candidates and being elected to councils. The variety of forms of local government make it difficult to aggregate the figures, but at the county council level in England there has been an increase in the percentage of women councillors from $15 \%$ in 1973 to $26 \%$ in 2000, with $24 \%$ of councillors elected in 2005 being women, ${ }^{19}$ while in Scotland there has been an increase from $10 \%$ in Scottish regions and $13 \%$ in Scottish districts in 1974 to $23 \%$ in Scottish councils in 2003 and 2007. ${ }^{20}$

Given the relatively low levels of women in local government in the United Kingdom, it is perhaps unsurprising that much of the academic literature has focused on barriers to participation and recruitment, including individual circumstances, structural factors and political culture, and that there has been relatively little analysis of women's progression to more senior positions within local authorities. In the 1990s Young and Rao, and Rao, suggested that women were proportionately as likely as men to hold senior positions, ${ }^{21}$ whilst Bochel and Bochel found a similar picture for England and Wales, but also that in Scotland women were still less likely than men to have progressed to senior positions in elected local government. $^{22}$

The current research covered every local authority in England, Scotland and Wales. Of those in England and Wales, where the new decision making arrangements had been introduced, the great majority (83\%) of councils had adopted the leader and cabinet model, 3\% (11 authorities) had a directly elected Mayor, and 1 council had a directly elected Mayor and a City Manager. Thirteen per cent of councils (54, all small authorities) had chosen the 'alternative arrangements' option. In Scotland, a small number of authorities had shifted to the cabinet model, but the majority retained the committee system.

The number of women councillors on authorities varied from 1 to 39 (a mean of 13), but perhaps more importantly, the percentage of councillors who were women ranged from $3 \%$ to 
$49 \%$, with a mean of $27 \%$, very much in line with other estimates for the country as a whole. In terms of the political parties, $31 \%$ of Liberal Democrat councillors were women, $27 \%$ of Labour councillors, $25 \%$ of Conservatives and $23 \%$ of Independents. Looking briefly at the question of whether there is any relationship between the levels of remuneration (as measured by the basic allowance paid to councillors) paid by different authorities and the proportion of women councillors, our analysis suggests that there is not.

It has sometimes been suggested that women are less likely to be represented in the most important political positions precisely because they are more important, as with the desirability hypothesis and the lag hypothesis ${ }^{23}$, and the evidence from this research would appear to support such a view, at least in relation to the leaders of local authorities, with a significantly lower proportion of council leaders being women. Across the United Kingdom, only $15 \%$ of leaders were women (19\% in Scotland, $15 \%$ in England and 13\% in Wales) and, where such a post existed, $15 \%$ of deputy leaders were women (16\% in Wales, $15 \%$ in England and $10 \%$ in Scotland). Only eleven councils had a woman as both leader and deputy leader, compared with 237 that had male leaders and deputy leaders. However, while these figures remain low, they do represent a marked increase on the $10 \%$ of authorities that we identified as having female leaders in the early stages of modernisation in $2001 .^{24}$ There appears to be no statistically significant relationship between the percentage of councillors who are women and the likelihood of an authority having a woman as leader. However, party does appear to have some influence here, with Labour, Conservative and Independent controlled councils being less likely (11, 15 and 17\% respectively) than Liberal Democrat controlled councils (26\%) to have women leaders. London Boroughs were by far the least likely type of authority to have women leaders, with only 2 from 32 authorities (6\%). Having noted above that there is no apparent relationship between the level of basic allowances and the proportion of women councillors it is perhaps worth noting that the same is true for the level of allowance for council leaders (which varied from $£ 583$ to $£ 71,856$ per year) and the sex of those leaders.

The introduction of new structures of decision making has inevitably changed the range of leadership positions within local government, with a shift away from committees, often with powerful chairs, to cabinets and executives with portfolio holders. A consideration of cabinets in England and Wales shows that these varied in size from 3 to 15 (with a mean of 8.4), while the number of women cabinet members varied from 0 to 9 (with a mean of 2.1, or slightly lower than proportionate in relation to the numbers of male and female councillors). The proportion of women on cabinets had increased slightly compared with that found in 2001. Twenty-eight councils (8\%) had no women in their cabinets, while no authorities had no men 
as cabinet members. There was a statistically significant relationship between the sex of the council leader and the proportion of the cabinet who are women (Pearson's $r=.302$, significant at the .01 level), with women leaders being more likely to have more women in their cabinet. However, given that only about one-third of councils give the leader the power to choose their cabinet, ${ }^{25}$ it is not clear whether this suggests that women leaders are more likely to choose women for their cabinets or whether there is some other explanation, such as that authorities with more politically powerful women are more likely to have one of those women as their leader. There was a stronger relationship between the percentage of councillors who are women and the proportion of the cabinet who are women (Pearson's $r=$ .420 , significant at the 0.01 level), and while this may in part simply be an artefact of having more women available (although in itself this is obviously important), it might also reflect other pressures that arise from having greater 'presence', including greater implicit expectation of more 'representative' proportions of women and men in senior positions.

It is also interesting to go beyond merely the numbers of men and women on cabinets to look at the type of portfolios that female and male cabinet members hold, and this has implications for some of the arguments around substantive representation, such as whether women representatives seek to act in the interests of women. While this inevitably requires a significant compression of a wide range of descriptions, and in some instances the responsibilities of cabinet members spread across more than one area, table 1 provides a useful illustration of the positions in 2001 and 2006.

1. Cabinet Members' Portfolios, 2001 and 2006, percentages

\begin{tabular}{lrrrr} 
& \multicolumn{2}{c}{2001} & \multicolumn{2}{c}{2006} \\
& Female & Male & Female & Male \\
Social Services/Inclusion/Welfare & 37 & 63 & 40 & 60 \\
Culture/Leisure & 14 & 86 & 33 & 67 \\
Housing & 13 & 87 & 37 & 63 \\
Environment/Sustainability & 29 & 71 & 27 & 73 \\
Education & 50 & 50 & 26 & 74 \\
Corporate Affairs & 16 & 84 & 13 & 87 \\
Regeneration/Economic Development & 15 & 85 & 18 & 82 \\
Transport & 20 & 80 & 17 & 83 \\
Community/Neighbourhood Services & 36 & 64 & 35 & 65 \\
Community Safety* & 0 & 100 & 27 & 73 \\
Customer Services** & & & 33 & 67 \\
Health** & & & 46 & 54 \\
Other & 27 & 73 & 26 & 74
\end{tabular}

*The Community Safety percentages for 2001 are skewed by the fact that there was only one council that had such a portfolio at that time.

**Not collected for 2001 as the numbers were very small. 
The table suggests that women councillors are proportionately more likely to hold portfolios relating to 'caring' areas, such as social services and social inclusion, housing, health and community and neighbourhood services, while they are less likely to have responsibility for spheres such as corporate affairs, regeneration and economic development and transport. Indeed, in these latter instances these differences can be seen even more clearly in some of the fields that we have included within these overall headings, with 42 out of 46 portfolio holders for regeneration, 36 out of 41 portfolio holders for finance, and 26 out of 29 portfolio holders for transport being men. In Scotland, where many authorities have retained the committee system for decision making, a similar pattern emerges, with, for example, $35 \%$ of chairs of social work committees being female.

In addition to the creation of cabinets/executives another feature of Labour's attempts to modernise local government in England and Wales was the introduction of scrutiny committees, intended to hold the executive to account and to evaluate policy, including potentially prospectively as well as retrospectively. The number of scrutiny committees varies widely, from one (including most district councils, many of which are quite small) to ten, with the mean being 3.8. Our results show that three-quarters of scrutiny committees were chaired by men, and one-quarter by women. As with cabinet portfolios, authorities also vary widely in the policy areas for which they establish scrutiny committees, but the same general pattern emerges as for portfolio holders, with women being more likely to chair scrutiny committees relating to 'caring' topics (see table 2).

2. Scrutiny Committee Chairs (examples), 2006, percentages

$\begin{array}{lcc} & \text { Female } & \text { Male } \\ \text { Children (92 committees) } & 41 & 58 \\ \text { Community/Leisure (57 committees) } & 35 & 65 \\ \text { Environment/Sustainability (142 committees) } & 20 & 80 \\ \text { Health (130 committees) } & 40 & 60 \\ \text { Overview/Scrutiny* (221 committees) } & 20 & 80 \\ \text { Regeneration (107 committees) } & 25 & 75 \\ \text { Resources (77 committees) } & 13 & 87 \\ \text { *Includes those authorities with only one committee. } & & \end{array}$

Clearly women are proportionately more likely to chair scrutiny committees relating to areas such as children, health and community/leisure services, are much less likely to chair those relating to resources, and are also somewhat less likely to chair committees relating to the environment/sustainability or general overview/scrutiny committees. 
Some have identified horizontal gender segregation in many spheres of life, including in politics, and these findings might appear to reflect such a view. However, while there are clearly some major differences in the extent to which responsibilities for different areas of council work are held by men and women, what is not clear from these figures is the extent to which these are, or are not, the choices of the individuals concerned, or are, the result of other influences, such as bias or stereotyping. The limited evidence that we were able to gather from previous studies in the 1990s, when there was even greater under-representation of women in senior positions in local government, suggested that women were generally happy with, and sometimes actively sought (although rarely in an attempt to substantively represent women), the positions which they held, but nevertheless we had retained some suspicion that this gender clustering of areas of responsibility reflected perceptions of areas of 'women's interests'. Among the questions that might be considered here, therefore, are what are the reasons for these gender differences in roles, and what, if any, is the impact of these upon councils' policy and practice? In terms of debates around the substantive representation of women, if it is assumed that critical actors are likely to be women, then their presence in policy areas of importance to many women could be viewed as positive, but the evidence does not necessarily support such an interpretation.

In relation to this latter point, what is of relevance and interest here therefore, is whether women are representing women's interests in these roles, and whether they are actively seeking to do so. It is of interest that these portfolios at least partly reflect the priority areas that Campbell identified amongst women at the 2001 general election. The fact that only around half of authorities give leaders the power to allocate portfolios to the members of their cabinets $^{26}$, and the degree of negotiation that takes place within and between political parties over the allocation of portfolios, means that at present it is not possible to explore this further. Further research needs to be undertaken on the preferences of leaders and portfolio holders, and the negotiations that take place on the formation of cabinets and the distribution of policy responsibilities. It is however worth noting that there does not appear to be any significant difference in the distribution of portfolios by sex across the different political parties.

\section{Representing women's interests?}

In the analysis of the more qualitative aspects of this research there are therefore a number of questions that we might start to explore, although the extent to which we are able to do this is inevitably limited by the data available. These include: the extent to which men and women councillors may seek to represent the interests of women; how they might do this through 
their leadership roles; and whether there are any perceptions of gender differences in approaches to leadership, emphases upon particular policy areas, or in networking.

Returning to the issue of descriptive representation, among those people to whom we have spoken, women were considerably more likely to support the idea of descriptive representation, such as with respect to gender and race, with around three quarters supporting such a notion (regardless of party), than men, of whom about half supported such a viewpoint. This would appear to reflect similar findings at the level of the Westminster Parliament and parliamentary candidates ${ }^{27}$ and might, perhaps, be a result of women being more likely to see their gender, and therefore descriptive representation, as important. Among councillors there was, however, widespread awareness of the barriers to this, both practical for individuals and in terms of the difficulties of getting measures adopted. Typical viewpoints were 'I totally support this... favour all-women shortlists' (Female, Independent), 'Yes, councils should be representative, but getting people to stand is difficult' (Female, Liberal Democrat), 'We are not into tokenism. It is a bit of a sideshow' (Male, Labour), 'I would like to see it happen, but I would reject any measures that would make it happen' (Male, Conservative). Several pointed out that this should extend beyond gender and 'race' so that councils should be generally more representative of their community. A number of respondents highlighted the difficulties of getting younger people on councils.

Again, reflecting findings such as those of Childs that women MPs felt that they had a different style from men, ${ }^{28}$ and perhaps suggestions from some academic work that the significant presence of women can impact upon political style and decision-making, women respondents were also far more likely to suggest (unprompted) that women operate differently from men (again, regardless of party), for example, putting forward views such as that women are more likely to seek consensus, take less directive approaches, be more open and transparent and to compromise than are men ('Women see more grey issues; more willing to compromise (Female, Labour); 'Women are more touchy feely, work more on consensus' (Female. Liberal Democrat), 'Women are more open, transparent' (Female, Conservative)), although a small number of men agreed with this view ('Women make better, more patient negotiators... a more consensual approach' (Male, Conservative)). Perhaps unsurprisingly, given these views, women were far more likely than men to identify skills such as communications and networking as important for councillors.

However, interestingly, and clearly relating to discussions of substantive representation and the extent to which women representatives seek, expect, or feel a responsibility to represent women, ${ }^{29}$ relatively few respondents, female or male, agreed that women bring different 
perspectives to issues or emphasise different policies or policy areas from men, with most suggesting that 'Overall there isn't much difference' (Female, Liberal Democrat), that 'Men's and women's issues are coming together - men are sharing roles' (Female, Conservative), or that it depends on the individual, although again a small number felt that different experiences might have an impact ('Men won't have experience of the same issues [such as] childbirth, so on some issues they are likely to have a different perspective' (Male, Conservative)). One council leader cited the example, from their authority, of relatively recently elected councillors from different ethnic groups, arguing that they had brought forward issues that might not otherwise have reached the council floor. So, whilst women councillors may be likely to hold positions that have often been associated with areas of interest or importance to women, they do not claim to be seeking to substantively represent women or to be acting in the interests of women, nor do they believe that they bring different perspectives or policy emphases. While some writers have argued that women representatives may feel a responsibility to act for women more generally, the evidence from this research does not particularly serve to either support or refute such a view. Indeed, it may be that with cultural change, in theory if not in practice, sex differences in relation to such claims might in any event be expected to diminish, as might also be expected with regard to leadership and management styles, as discussed below.

The view of respondents that there is little or no difference in the perspectives and policy priorities of female and male councillors, serves to further confuse possible interpretations around the differences in cabinet portfolios (and indeed scrutiny committees chaired) identified earlier, particularly when combined with the wide range of constraints that act upon leaders (the variety of mechanisms that exist include, in some instances, ruling parties, and in others, entire councils, voting for cabinets (sometimes extending to electing or approving specific individuals for each portfolio)). This situation is made even more unclear by the growing number of authorities where no one party has an overall majority. It is unsurprising therefore, that many of those to whom we spoke recognised that there is a process of discussion and negotiation in choosing cabinet members and in the allocation of portfolios. However, the majority of respondents, both female and male, from all parties and across different types of councils, felt that there was no hierarchy of portfolios ('with the previous leader there was. This mirrored the old [committee system] council' (female, Conservative); 'I have tried to balance portfolio responsibilities' (male, Labour), and where such a thing was identified, it was often seen as being because a particular post was held by a deputy leader, or for specific local reasons, such as that roads or education were currently a high profile issue in the area. The fact that women are more likely to hold responsibilities in some policy areas does not therefore appear to reflect any difference in status or power across cabinets, certainly 
as measured by councillors themselves. This is arguably different from the situation prior to 'modernisation', where the chairs of some committees, frequently those most likely to be chaired by men, were generally seen as having greater power and influence than others.

There were also two other findings that might potentially relate to debates about women and substantive representation, and in particular to the extent that women (seek to) represent women. Firstly, women were no more likely than men to report that they had experience with community issues and community groups before entering politics, a finding that fits well with the literature that suggests that women are more likely to become involved in politics via mechanisms outside the political mainstream. Secondly, however, women were significantly more likely than their male counterparts to report that they had other political commitments, although in this instance these were frequently directly related to their local government role, rather than to involvement in other groups or organisations that might have been expected to act as mechanisms for links with other women.

The information gleaned from the interviews is again somewhat contradictory in relation to debates and evidence on gendered political leadership, and in particular the view that women politicians operate differently from men. Although, as noted earlier, women were likely to say that they do adopt different approaches from men, when asked specifically about their leadership styles, the majority of respondents, female and male, suggested that they 'seek to be inclusive' (Labour, male), are 'less confrontational and more consensual' (female, Conservative) and 'informal and participative' (male, Conservative), although some still emphasised that they are 'willing to have conflict and make tough decisions' (female, Conservative). After 'inclusiveness', the most commonly used phrases were 'consensual' and 'transparent'; many respondents argued that they wished to have more transparent decision making, frequently citing their predecessors as not having had this, but several also stressed that they were 'willing to make tough decisions'. Perhaps unsurprisingly they identified skills such as strategic thinking, networking, communication, 'managerial' and IT skills as important for council leaders. Overall there was little difference in responses between men and women, with both being far more likely to say that they were inclusive than any other response, and with women being just as likely as men to say that they were willing to make tough decisions (although it was only women who identified transparency as one of their traits).

\section{Conclusions}

In terms of the descriptive representation of women, the results presented in the first section of analysis in this article provide a comprehensive picture of the position in 2006. On the face 
of it, the reforms that the Labour governments have introduced since 1997, particularly in England and Wales, appear to have made relatively little difference, with trends such as the gradual increase in the number of women councillors continuing, and a continued closing of the gender gap in relation to senior posts, such as portfolio holders in cabinets, although the numbers of women reaching the position of leader or deputy leader of councils remains lower than would be expected in relation to the numbers of women who are elected to local authorities.

Despite their under-representation amongst council leaders, it does not appear likely that women are losing out more than previously as a result of the increased concentration of power among the small groups that form the cabinets, particularly in England and Wales, compared with the larger committees under the previous structures. This is because the relative underrepresentation of women in the positions of council leader (and deputy leader, where such a position exists) does not appear to be reflected in the make-up of cabinets which, on average, now roughly reflect the proportions of female and male councillors, again a change from the position in 2000/2001. This almost inevitably leads to the question of whether and when the proportion of council leaders who are women will come to reflect the proportion of cabinet members who are women, as might be expected from perspectives such as that of the lag hypothesis. However, perhaps more immediately of interest are the differences in portfolio responsibilities, and in particular the extent to which women councillors are proportionately more likely to oversee certain areas, such as social services, housing, health and community or neighbourhood services, and are much less likely to have lead roles in others, such as transport and regeneration/economic development. The ways in which these portfolios are allocated are an important area for further examination, clearly in relation to gender, but also to other factors such as party, and the relationships between leaders and the members of cabinets. Similarly, the apparent relationship between women leaders and the proportion of women in cabinets is also worthy of exploration - do women leaders choose to have more women in their cabinets, or are there other influences at work, such as perhaps the presence of politically powerful women making it more likely that a women will become leader? The greater proportionality of numbers of men and women in cabinets in relation to male and female councillors has also been reflected in the chairing of scrutiny committees, although the gender differences in areas of responsibility are also evident in these roles, and the reasons for this are again unclear. A significant question may again be the extent to which female and male councillors exercise choice over which scrutiny committees they chair. As noted above, there is a literature, including that around critical actors, which suggests that some representatives may be much more motivated than others to pursue women-friendly policies. 'Presence' in positions of responsibility in the right policy areas would be likely to be one 
means of doing this, and this research suggests that local government would provide a fruitful ground for further work in this field.

However, on the extent to which women in leadership positions in local government seek to represent women, the evidence from this research is mixed. Women in such positions in local authorities do appear to be more likely than their male counterparts to support descriptive representation (although they are not necessarily more enthusiastic about particular mechanisms to achieve this), and are more likely to argue that in politics women operate differently from men. While there is clear evidence that they are more likely to hold leadership positions in areas which might traditionally have been seen as relating to 'women's interests'; it is here that the evidence becomes more confused, since, as noted above, the extent to which individuals are exercising choice over these roles is unclear. This is another area worthy of further exploration in the future, as it has significant implications for debates about the substantive representation of women, since it may be possible to consider the extent to which individuals are seeking to act (or not) for the substantive representation of women and the policy arenas in which they do so.

Yet, few respondents, male or female, agreed with the proposition that women are more likely to hold different perspectives on policy areas, and there was relatively little suggestion that women are more likely to voice women's concerns or prioritise particular interests or policy areas (areas where the evidence from the parliamentary level is mixed). One possible interpretation of these results might therefore be that senior women councillors are more likely to favour descriptive representation, perhaps on the grounds of justice or legitimacy, but that they do not expect (or possibly wish for) particular policy responses or greater or different substantive representation to result from this? However, it may be that the answer to whether there is any fostering of the substantive representation of women depends upon the interpretation of findings such as the distribution of portfolios and areas of responsibility between men women, an area which remains very unclear, and the policy outcomes that arise from these.

Finally when asked about their leadership styles, both men and women councillors tended to use similar language and arguments, with, from their point of view, any perceived contrast typically being with their predecessors, rather than with the other sex. The research therefore finds relatively little direct support for the idea of gendered political leadership, although the key fact remains that at the most senior levels in elected local government, women remain underrepresented, even in relation to the proportion of councillors who are female. 


\section{Funding}

Nuffield Foundation Small Grants Scheme (SGS/32112).

${ }^{1}$ Office of the Deputy Prime Minister, Vibrant Local Leadership, ODPM, 2005.

${ }^{2}$ Department for Communities and Local Government, Strong and Prosperous Communities, The Stationery Pffice, 2006.

${ }^{3}$ Office of the Deputy Prime Minister, Vibrant Local Leadership, ODPM, 2005.

${ }^{4}$ Office of the Deputy Prime Minister, Equality and Diversity in Local Government in England: A Literature Review, ODPM, 2003.

${ }^{5}$ Department for Communities and Local Government, Strong and Prosperous Communities, The Stationery Office, 2006.

${ }^{6}$ D. Wilson and C. Game, Local Government in the United Kingdom, Palgrave Macmillan, 2002.

${ }^{7}$ M. Bennett, J. Fairley and M. McAteer, Devolution in Scotland: The Impact on Local Government, Joseph Rowntree Foundation, 2002.

${ }^{8}$ M. Laffin, G. Taylor and A. Thomas, A New Partnership? The National Assembly for Wales and Local Government, Joseph Rowntree Foundation, 2002.

${ }^{9}$ A. Phillips, The Politics of Presence, 1998, Oxford University Press; A. Phillips, 'Representing Difference: Why Should it Matter if Women Get Elected', in A. Coote (ed.) New Gender Agenda, 2000, Institute for Public Policy Research.

${ }^{10}$ R. Campbell, 'Gender, Ideology and Issue Preference: Is There Such a Thing as a Political Women's Interest in Britain?', British Journal of Politics and International Relations, 6, 2004, 20-44, p. 41.

${ }^{11}$ J. Mansbridge, 'Should Blacks Represent Blacks and Women Represent Women? A Contingent "Yes"”, Journal of Politics, 61, 1999, 628-57.

${ }^{12}$ I. Young, Inclusion and Democracy, Oxford University Press, 2000.

${ }^{13}$ S. Dovi, 'Preferable Descriptive Representatives: Will Just Any Woman, Black or Latino Do?', American Political Science Review, 96, 2002, 729-43.

${ }^{14}$ S. Childs and J. Withey, 'The Substantive Representation of Women: The Case of the Reduction of VAT on Sanitary Products', Parliamentary Affairs, 59, 2006, 10-23.

${ }^{15}$ K. Celis, S. Childs, J. Kantola and M. Krook, 'Rethinking Women's Substantive Representation', paper presented to the European Consortium for Political Research Joint Sessions of Workshops, Helsinki, May 7-12 2007.

${ }^{16}$ N. Norton, 'Women, It's Not Enough to Be Elected: Committee Position Makes a Difference', in G. Duerst-Lahti and R. Kelly (eds.) Gender Power, Leadership and Governance, University of Michigan Press, 1995.

${ }^{17}$ H. Elcock, 'Council Leaders in the "New Britain": Looking Back and Forward', Public Money and Management, 18, 1998, 15-21; N. Rao, Councillors and the New Council Constitutions, Office of the Deputy Prime Minister, London, 2005.

${ }^{18}$ C. Bochel and H. Bochel, 'Modernisation of Backward Step? Women Councillors and New Decision-Making Structures in Local Government', Local Government Studies, 30, 2004, 36-50.

${ }^{19}$ Local Government Chronicle Elections Centre, http://www.research.plymouth.ac.uk/elections/elections/2005\%20results.htm, accessed 21 August 2007.

${ }^{20}$ J. Bochel and D. Denver, Scottish Local Elections 1974:Results and Statistics, Election Studies, 1974; H. Bochel and D. Denver, Scottish Council Elections 2003: Results and Statistics, Election Studies, 2003.

${ }^{21}$ K. Young and N. Rao, Coming to Terms with Change? The Local Government Councillor in 1993, Joseph Rowntree Foundation/LGC Communications, 1994; N. Rao, 'The Representation of Women in Local Politics', Policy and Politics, 3, 2005, 323-39.

${ }^{22}$ C. Bochel and H. Bochel, The Careers of Councillors, Ashgate, 2000.

${ }^{23}$ See, for example, R. Engstrom, M. McDonald and B. Chou, 'The Desirability Hypothesis and the Election of Women to City Councils: A Research Note', State and Local Government Review, 20, 3840; J. Lovenduski, Feminizing Politics, Polity, 2005.

${ }^{24}$ C. Bochel and H. Bochel, 'Modernisation of Backward Step? Women Councillors and New Decision-Making Structures in Local Government', Local Government Studies, 30, 2004, 36-50. 
${ }^{25}$ G. Stoker, F. Gains, P. John, N. Rao and A. Harding, Implementing the 2000 Act with Respect to New Council Constitutions and the Ethical framework. First Report, 2003, http://www.elgnce.org.uk/firstreportelg.pdf, accessed 22 August 2007.

${ }^{26}$ F. Gains, S. Greasley and G. Stoker,A Summary of Research Evidence on New Council Constitutions in Local Government, Office of the Deputy Prime Minister, 2004.

${ }^{27}$ P. Norris, 'Women Politicians: Transforming Westminster' in J. Lovenduski and P. Norris (eds.) Women in Politics, Oxford University Press, 1996; J. Lovenduski and P. Norris, 'Westminster Women: the Politics of Presence', Political Studies, 51, 2003, 84-102.

${ }^{28}$ S. Childs, New Labour's Women MPs: Women Representing Women, Routledge, 2004; S. Childs, 'A Feminised Style of Politics? Women MPs in the House of Commons', British Journal of Politics and International Relations, 6, 2004, 3-19.

${ }^{29}$ S. Carroll, 'Representing Women. Women State Legislators as Agents of Policy-Related Change', in S. Carroll (ed.) The Impact of Women in Public Office, Indiana University Press, 2001; S. Childs, 'In Their Own Words: New Labour Women and the Substantive Representation of Women', British Journal of Politics and International Relations, 3, 2001, 173-90; M. Diaz, Representing Women? Female Legislators in West European Parliaments, ECPR Press, 2005.

Linked to this, if the argument is accepted that local government is more accessible to women and that it is often concerned with services that impact directly on women's lives, then it may be that there is indeed the representation of women's interests by women. 